\title{
Electricity generation from biogas of poultry slaughterhouse biomass in Matelandia - Brazil
}

\author{
Diana Fatima Formentini ${ }^{1, *}$, Guilherme de Paula Mmoreira Fracaro ${ }^{1}$, Ricardo Nagamine \\ Costanzi $^{1}$, Samuel Nelson. Melegari de Souza ${ }^{1}$, Cleber Aimone Marques ${ }^{1}$ \\ ${ }^{1}$ UNIOESTE/CASCAVEL/CCET/PPGEA - Universidade Estadual do Oeste do Paraná - Programa de Pós \\ Graduação em Energia na Agricultura - Rua Universitária 2069 - Jardim Universitário- Cascavel/Paraná- \\ Brasil- 85819-110 \\ *Corresponding author: Tel.: +55 45 32203151; E-mail: mpbambiental@yahoo.com.br
}

\begin{abstract}
Brazil has great potential for biomass production. There are several processes to convert biomass into energy, among these is the biological conversion of organic carbon into methane. This work aimed to estimate the production of biogas in a poultry slaughterhouse in Matelandia state of Paraná, Brazil, by the IPCC methodology. The poultry slaughterhouse slaughter 140,000 poultries a day and generates a wastewater FLOW OF $3,360 \mathrm{~m}^{3} \cdot \mathrm{d}^{-1}$. Electricity consumption by the industry plant is about 3,600 MWh.month ${ }^{-1}$. The treatment system used in industry is the physical and biological process, and the pre-treatment consists of a static sieve and a flotation equipment, followed by stabilization ponds. Two anaerobic ponds were covered with a geomembrane of High Density Polyethylene and was installed a gas meter to measure the flow rate of biogas production. The biogas generation potential estimated can reduce $3.89 \%$ of the electricity consumed.
\end{abstract}

Keywords: Bioenergy, Anaerobic digestion, Wastewater, IPCC.

\section{Introduction}

In the past decades, the consumption of meat chicken in many countries has been on the increase. As a result of the growing poultry industry, poultry slaughterhouses are producing increasing amounts of by-products and wastes ${ }^{1}$.

The production and export of chicken meat perform an important role in the Brazilian economy. According to the ABEF - Brazilian Association of Chicken Producers and Exporters, in 2009, Brazil was among the international reach first place in the export sector and third in world production of chicken meat, behind the United States and China. The southern region of Brazil has an important role in the achievement of these data, because it focuses on the major poultry production and consequently the processing industries of chicken meat, accounting for approximately $75 \%$ of national production. The State of Paraná is the largest producer of chicken meat from Brazil, exporting in the year 2009 a total of 954,6535 tonnes of chicken meat ${ }^{2}$.

The interest in recovering the biogas generated by stations for sewage treatment, urban solid waste landfills, residue of sugar cane, by the biodigestion of the vinasse, livestock manure anaerobic digestion and poultry slaughterhouse wastewater associated with its energetic use and managing these residues, have been discussed in Brazil ${ }^{3}$.

Anaerobic digestion is a biological process that occurs in the absence of oxygen, where organic matter is degraded and transformed in gaseous mixture called biogas. The biogas composition is highly variable depending on various aspects like the characteristics of biomass and environmental conditions offered. The average composition of biogas has the following values: $\mathrm{CH}_{4}$ (50-75\%), $\mathrm{CO}_{2}$ (25-50\%), $\mathrm{N}_{2}(0-10 \%), \mathrm{H}_{2}(0-1 \%), \mathrm{H}_{2} \mathrm{~S}(0-3)$ and $\mathrm{O}_{2}$ $(0-2)^{4}$. 
Wastewater as well as its sludge components can produce $\mathrm{CH}_{4}$ if it degrades anaerobically. The extent of $\mathrm{CH}_{4}$ production depends primarily on the quantity of degradable organic material in the wastewater, the temperature, and the type of treatment system. With increases in temperature, the rate of $\mathrm{CH}_{4}$ production increases. Below $15^{\circ} \mathrm{C}$, significant $\mathrm{CH}_{4}$ production is unlikely because methanogens are not active and the lagoon will serve principally as a sedimentation tank. However, when the temperature rises above $15^{\circ} \mathrm{C}, \mathrm{CH}_{4}$ production is likely to resume ${ }^{5}$.

This paper objectives to evaluate the potential for methane production in a poultry slaughterhouse by the IPCC methodology, and the potential for generating electricity from the energy use of the methane produced in anaerobic digestion process.

\section{Methodology}

\subsection{Water consumption and wastewater characteristics in poultry slaughterhouses}

The according to the sanitary requirements related to processing and industrialization of meat, the demand for water in this activity is high, it can be considered an average consumption of 25 a $50 \mathrm{~L}^{6}, 25 \mathrm{~L}^{7,8}$ ou $17 \mathrm{~L}$ a $20 \mathrm{~L}$ by poultry slaughtered ${ }^{9}$.

It is recognized that minimising water consumption and contamination has wide reaching environmental benefits. Increasing the volume of water used automatically affects the volume of waste water which has to be treated at either an on-site or a municipal waste water treatment plant. Water makes contact with a carcass or any animal by-product, whether during production or cleaning, contaminants such as fats or blood are entrained and these increase the burden on the waste water treatment plant. In many cases the water used is hot, so energy will have been used to heat it. Also the fats can melt in hot water and then become more difficult to separate from the water ${ }^{5}$.

The references of wastewater characteristics available in the literature described in Table 1, have several values due different water consumption by poultry slaughtered, operational practices, size of the industry, collecting the effluent at different points, among others.

Table 1: Characteristics of wastewater poultry slaughterhouse

\begin{tabular}{|c|c|c|}
\hline References & $\mathrm{COD}\left(\mathrm{mgO}_{2} \cdot \mathrm{L}^{-1}\right)$ & BOD $\left(\mathrm{mgO}_{2} \cdot \mathrm{L}^{-1}\right)$ \\
\hline AGUILAR, et al., $2005^{10}$ & 5,400 & 2,760 \\
\hline CHAVEZ, et al., $2005^{11}$ & 7,333 & 5,500 \\
\hline DORS, $2006^{12}$ & 6,720 & 4,434 \\
\hline MARQUES, $2007^{13}$ & 4,325 & 3,346 \\
\hline DE NARDI, et al., $2008^{14}$ & 6,880 & - \\
\hline AMORIM, et al., $2008^{15}$ & 3,102 & - \\
\hline $\begin{array}{l}\text { MATSUMURA \& MIERZWA, } \\
2008^{16}\end{array}$ & 9,115 & 4,593 \\
\hline
\end{tabular}

\subsection{Characterization of the case study}

The industrial plant slaughter 140,000 poultry. $\mathrm{d}^{-1}$, generating a flow of wastewater from 3.360 $\mathrm{m}^{3} \cdot \mathrm{d}^{-1}$, resulting in 24 L.poultry slaughtered ${ }^{-1}$.

The wastewater treatment system use in the industry is compound by categories pretreatment, primary and secondary through the physical and biological processes. Pretreatment consists of a static sieve to remove solids, the primary treatment in flotation 
equipment for the physical process for removal of oils and greases and secondary treatment is the arrangement of two biodigesters in parallel, an aerated pond with aeration sub- surface endowed with aerators and 6 also air vents and a facultative pond.

The main physical and chemical characteristics of wastewater are COD average Biodigester influent: 3,390 $\pm 1,275 \mathrm{mg} \mathrm{L}^{-1}$ and COD average Biodigester effluent: 1,205 $\pm 300 \mathrm{mg} \mathrm{L}^{-1}$.

Measurements of water consumption were made by water meters installed at seven points of the production process, which resulted in consumption values by sector.

The industry in question has a demand of 3,360 $\mathrm{m}^{3} \cdot \mathrm{d}^{-1}$ accounting for water consumption in all productive sectors, from receipt of the birds, washing trucks, bleeding, scalding, evisceration, cooling room, cuts, water sanitation cleaning equipment and industrial plant, boiler until the dispatch of meat.

Electricity consumption from the poultry slaughterhouse is 3,600 MWh.month ${ }^{-1}$, resulting in approximately $1.07 \mathrm{kWh}$.poultry slaughtered ${ }^{-1}$.

\subsection{Estimate of the methane potential production}

The principal factor in determining the $\mathrm{CH}_{4}$ generation potential of wastewater is the amount of degradable organic material in the wastewater. Common parameters used to measure the organic component of the wastewater are the Biochemical Oxygen Demand (BOD) and Chemical Oxygen Demand (COD). Under the same conditions, wastewater with higher COD, or BOD concentrations will generally yield more $\mathrm{CH}_{4}$ than wastewater with lower COD (or BOD) concentrations ${ }^{5}$.

Considering the IPCC Guidelines for National Greenhouse Gas Inventories - Chapter 6: Wastewater Treatment and Discharge, was used following the methodology to account the methane production potential in poultry slaughterhouse in Matelandia, Paraná, Brazil.

Emissions are a function of the amount of organic waste generated and an emission factor that characterises the extent to which this waste generates $\mathrm{CH}_{4}$.

Three tier methods for $\mathrm{CH}_{4}$ from this category are summarised below:

The Tier 1 method applies default values for the emission factor and activity parameters. This method is considered good practice for countries with limited data.

The Tier 2 method follows the same method as Tier 1 but allows for incorporation of a country specific emission factor and country specific activity data. For example, a specific emission factor for a prominent treatment system based on field measurements could be incorporated under this method. The amount of sludge removed for incineration, landfills, and agricultural land should be taken into consideration.

For a country with good data and advanced methodologies, a country specific method could be applied as a Tier 3 method. A more advanced country-specific method could be based on plant-specific data from large wastewater treatment facilities.

This paper follow the Tier 2 method.

Step 1: Estimate total organically degradable carbon in wastewater (TOW) for industrial 
sector i.

$$
\mathrm{TOWi}=\mathrm{Pi} \cdot \mathrm{Wi} \cdot \mathrm{CODi}
$$

Where:

TOWi = total organically degradable material in wastewater for industry $i, \mathrm{~kg}$ COD/yr $\mathrm{i}=$ industrial sector

$\mathrm{Pi}=$ total industrial product for industrial sector $i, \mathrm{t} / \mathrm{yr}$

$\mathrm{Wi}=$ wastewater generated, $\mathrm{m}^{3} / \mathrm{t}$ product

CODi $=$ chemical oxygen demand (industrial degradable organic component in wastewater)

kg.COD.m ${ }^{-3}$

Step 2: Select the pathway and systems according to country activity data. Use Equation 2 to obtain emission factor. For each industrial sector estimate the emission factor using maximum methane producing capacity and the average industry-specific methane correction factor.

$$
E F j=B o \cdot M C F j
$$

Where:

$\mathrm{EFj}=$ emission factor for each treatment $/$ discharge pathway or system, $\mathrm{kgCH}_{4} / \mathrm{kg}$.COD

$\mathrm{j}=$ each treatment/discharge pathway or system

Bo = maximum $\mathrm{CH}_{4}$ producing capacity, kg. $\mathrm{CH}_{4} / \mathrm{kg}$.COD

$\mathrm{MCFj}=$ methane correction factor

Good practice is to use country and industry sector specific data that may be available from government authorities, industrial organizations, or industrial experts. However, most inventory compilers will find detailed industry sector-specific data unavailable or incomplete. If no country-specific data are available, it is good practice to use the IPCC COD-default factor for Bo (0.25 $\mathrm{kg} \mathrm{CH}_{4} / \mathrm{kg}$.COD).

\subsection{Electricity Generation Potential}

The estimate electricity generation potential by the biogas produced was calculated following this equation:

$$
P_{e l}=\frac{P C I_{C H 4} * M J * P_{C H 4} * \eta_{e l}}{k W h * 1000 * 100}
$$

Onde:

$\mathrm{P}_{\mathrm{el}}$ : Electricity generation potential MWh.year ${ }^{-1}$;

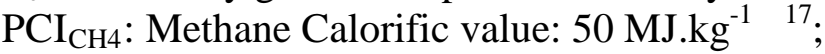

$\frac{M J}{k W h}$ : Unit conversion factor: 0,2778 ;

$\eta_{e l}$ : Electricity Generation System Efficiency: \%.

\section{Results}

The methane generation potential is 515,963 $\mathrm{kgCH}_{4} \cdot \mathrm{year}^{-1}$, equivalent $1.414 \mathrm{kgCH}_{4} \cdot \mathrm{d}^{-1}$. Considering a electric generation efficiency of $30 \%$ for the motor, the methane generation can produce 1,681 MWh.year ${ }^{-1}$, or 4.61 MWh.d $\mathrm{M}^{-1}$. 


\section{Conclusion}

The biogas produced by the anaerobic digestion process can reduce $3.89 \%$ of the electric energy consumption at poultry slaughterhouse.

\section{Acknowledgments}

The authors acknowledge ITAI - Instituto de Tecnologia Aplicada e Inovação, FPTI Fundação Parque Tecnológico de Itaipu and FINEP - Financiadora de Estudos e Projetos for the operacional and financial support.

\section{References}

[1] Salminen, E.; Rintala, J.; Anaerobic digestion of organic solid poultry slaughterhouse waste - a review; Bioresource Technology; 83; pp. 13-26; 2002.

[2] ABEF - Associação Brasileira dos Produtores e Exportadores de Frango - Relatório Anual, 2009/2010.

[3] Salomon K. R., Lora, E. E. S. Estimate of the electric energy generating potential for different sources of biogas in Brazil. Biomass and Bioenergy, 33, p. 1101 - 1107. 2009.

[4] Speight, J.G.; Synthetic fuels handbook; 1ª Edição; Editora McGraw-Hill; pg 351; 2008.

[5] IPCC; Guidelines for National Greenhouse Gas Inventories; Chapter 6; 2006.

[6] CETESB - Companhia de Tecnologia e Saneamento Ambiental \& SMA-SP - Secretaria do Meio Ambiente do Estado de São Paulo; Relatório técnico n. 2 do convênio SMA/MCT n. 01.0053.00/2001 - Efluentes; 2003. Disponível em www.mct.gov.br/CLIMA/brasil/pdf/Efluente_preliminar.pdf. Acesso em: 20/07/2010.

[7] SUDERHSA - Superintendência De Desenvolvimento De Recursos Hídricos E Sanemanento Ambiental. Manual Técnico de Outorgas; Novembro de 2006.

[8] Mierzwa, J. C.; Hespanhol, I. Água na Indústria - Uso - Uso Racional e Reúso; São Paulo. Ed. Oficina de Textos;143 pg; 2005.

[9] Philippi Jr, Arlindo., Bruna, Gilda Collet., Romero, Marcelo De Andrade; Curso de Gestão Ambiental; 1045 p. $1^{\text {a }}$ Ed. São Paulo; 2004.

[10]Aguilar, M. I., Saéz, J., Llórens, M., Soler, A., Ortunõ, J. F., Meseguer, V., Fuentes, A.; Improvement of coagulation-flocclation process usinganionic polyacrylamide as coagulation aid; Chemosphere; 58 47-56; 2005.

[11]Chavez, C. P., Castillo, R. L., Dendooven, L., Escamilla-Silva, E. M., Poultry slaughter wastewater treatment with an up-flow anaerobic sludge blanket (UASB) reactor; Bioresource Technology; 96; 1730-1736; 2005.

[12] Dors, Gisenara. Hidrólise Enzimática e Biodigestão de Efluentes da Indústria de Produtos Avícolas; Dissertação de Mestrado - Programa de Pós-Graduação em Engenharia Química. Universidade Federal de Santa Catarina - UFSC; 2006.

[13] Marques, Valmir; Kato, Mario T., Florencio, Lurdinha. Caracterização e Avaliação da Eficiência do Tratamento de Efluentes de Abatedouro Avícola na Região do Semi-Árido. $24^{\circ}$ Congresso Brasileiro de Engenharia Sanitária e Ambiental. Belo Horizonte - MG, 2007. 
[14]De Nardi, I.R., T.P. Fuzi A, V. Del Nery; Performance evaluation and operating strategies of dissolved-air flotation system treating poultry slaughterhouse wastewater; Resources, Conservation and Recycling; 52; 533-544; 2008.

[15]Amorim, A.K.B., De Nardi, I.R., Del Nery, V. Water conservation and effluent minimization: Case study of a poultry slaughterhouse. Resources, Conservation and Recycling; 51; 93-100; 2007.

[16] Matsumura, E.M., Mierzwa, J. C. Review - Water conservation and reuse in poultry processing plant- A case study; Resources, Conservation and Recycling 52; 835-842; 2008.

[17]Heywood, J.B.; Internal combustion engine Fundamentals; Editora McGraw-Hill; pg 915; Nova Iorque; 1988.

[18]UNFCCC; Report of the subsidiary body for scientific and technological advise on its eighteenth session; Junho; 2003. 